\title{
TASK-BASED LANGUAGE LEARNING: INVESTIGATING THE DYNAMICS OF LEARNERS' ORAL INTERACTION
}

\author{
Hazleena Baharun ${ }^{1 *}$, Harison Mohd Sidek ${ }^{2}$, Mohd Muzhafar Mohd Idrus ${ }^{3}$ and Noor \\ Saazai Mat Saad ${ }^{4}$ \\ 1Dr., Islamic Science University of Malaysia, MALAYSIA, hazleena@usim.edu.my \\ ${ }^{2}$ Assoc. Prof. Dr., Islamic Science University of Malaysia, MALAYSIA, harison@usim.edu.my \\ ${ }^{3}$ Dr., Islamic Science University of Malaysia, MALAYSIA, muzhafaridrus@usim.edu.my \\ ${ }^{4}$ Dr., Islamic Science University of Malaysia, MALAYSIA, noorsaazai@usim.edu.my \\ ${ }^{\star}$ Corresponding author
}

\begin{abstract}
For learning to occur, interaction among learners is vital. Interaction is crucial as a channel for exchanging knowledge that would promote both development and learning. In second language learning, interaction has always been regarded as important in the language classroom as it is believed that language is best learned and taught through interaction. Interaction is important due to its contribution to gains in second language (L2) acquisition. One possibility of providing interaction opportunities to learners is through the use of tasks. The aim of this study was to investigate how learners of English as a foreign language (EFL) interacted during task completion. The investigation focused on the dynamics of learner interaction and the kind of oral interactions generated by the participants. Two different communication task types were used in this study i.e. jigsaw and decision-making. The data for the study comprised transcribed recordings of learner interaction working on both given task types. They were analyzed focusing on the social processing. Findings revealed that the participants attempted task completion collaboratively for both task types. The collaborative interaction was characterized by argumentative episodes. However, close examination showed that the participants engaged in more intensive argumentative negotiations which were highly collaborative during decision-making task completion than during task completion of the jigsaw task type. The results suggest that communication task types can be used to elicit collaborative interaction episodes with argumentative negotiations and these kinds of interactions are believed to be important particularly for learners at the tertiary level. The findings are discussed in relation to their pedagogical implications in the EFL classrooms.
\end{abstract}

Keywords: oral interaction, collaborative interaction, argumentative episodes, communication tasks

\section{INTRODUCTION}

According to Gerlach (1994), learning occurs through interaction with others. Linguists and psychologists concur that interaction is crucial as a means of exchanging knowledge that would promote both development and learning (Franco, 1996). One perspective of research that stresses on the role of social interaction is framed in the Vygotskian's Socio-Cultural Theory (SCT). From the SCT perspective, language in the form of interaction is used by learners collaboratively to construct shared meanings. It is seen as a tool for meaning- 
making. The whole process of collaborative talk allows meaning to be made, negotiated, argued and shared. This suggests that interaction and context are not separated from one another or from the learning situation. The underlying assumption is that knowledge is created through interaction and not simply transferred. It is then internalised (Vygotsky, 1978).

According to the SCT, functions that are initially performed collaboratively with others through interpersonal interaction are then performed independently by the individuals. The interpersonal interaction is one type of mediation that is of particular importance for learning. It is this type of social interaction that enables the basic mental functions to evolve into more complex functions. It is a social behavior that occurs when an individual communicates with another. It can happen face-to-face through the oral medium or it can involve the written medium. In the SCT, then, interaction is not just a "device that facilitates learners movement along the interlanguage continuum, but a social event which helps learners participate in their own development, including shaping the path it follows" (Ellis, 1999, p. 20). Thus, interaction can be viewed both as social as well as private. An interaction is considered a social interaction when learners converse with other learners in a social setting. What these learners do is communicate while working together. When this happens, learning is shaped and constructed. An interaction is considered private when learners interact with themselves.

\section{INTERACTION AND SECOND LANGUAGE LEARNING}

In second language learning (L2), social interaction has always been regarded as important in a language classroom as it is believed that language is best learned and taught through interaction. When learners interact, they engage in various activities such as repeating themselves, providing explanations and giving details in order to ensure their ideas and messages get across (Olsen \& Kagan, 1992). These activities are believed to contribute to gains in second language acquisition (SLA).

L2 researchers who work on the role of social interaction in language acquisition believe that social interaction is an opportunity to learn (e.g. Brooks, Donato \& McGlone, 1997; Lantolf, 2000; Ohta, 1995). They argue that during social interaction, as they work collaboratively and negotiate, learners have the opportunity to develop not only their language skills but also their cognitive and problem solving abilities (Swain \& Lapkin, 2002). When SCT perspective is applied to second language learning, it has led to an increasing interest in collaborative dialogue, a kind of dialogue where language use and language learning occur simultaneously as learners interact (Donato, 1994; Swain, 2000; Swain \& Lapkin, 2000, 2002). It is when learners "engaged in problem-solving and knowledge-building" (Swain, 2000, p.102) which usually occur when they encounter linguistic problems and try to solve them together. From this perspective, language is viewed as social activity as well as cognitive activity. Both aspects are deemed important in language learning.

Considering the emphasis placed on collaborative interaction in promoting learning by the SCT, one way to promote or encourage L2 learners to interact with one another is through the use of communication tasks in the language classrooms. Studies in second language pedagogy advocate the use of tasks which require learners to produce output collaboratively as learner collaboration in groups or pairs promote language learning (e.g., Swain \& Lapkin, 2000, 2001). The output which surfaces when learners collaborate especially in solving linguistic problems they encountered in communicative task completion represents second language learning in progress (e.g., Donato, 1994).

What constitutes a task? Bygate, Skehan and Swain (2001) define a task as "an activity which requires learners to use language, with emphasis on meaning, to attain an objective" (p.11). According to Lee (2000), a task is "(1) a classroom activity or exercise that has: (a) an objective obtainable only by the interaction among participants, (b) a mechanism for structuring and sequencing interaction, and (c) a focus on meaning exchange; (2) a language learning endeavour that requires learners to comprehend, manipulate, and/or produce the target language as they perform some set of workplans." Research on tasks demonstrates that their use in second language classrooms promotes communication, interaction and negotiation (e.g., Ellis, 2004; Mackey, 2007; Nassaji \& Tian, 2010; Pica, Kanagy, \& Falodun, 1993). Hence, tasks are tools that can promote interaction as well as give room for the process of negotiation for meaning to take place.

\section{THE STUDY}

Studies have empirically shown that the use of communication tasks in language classrooms provides opportunities for learners to interact (Nassaji \& Tian, 2010; Nuevo, Adams \& Ross-Feldman, 2011). Certain task types encourage learners to interact more, hence engage in episodes of negotiated interaction and modified output. Producing output has been seen as beneficial to second language learning within SLA (Nuevo, Adams \& Ross-Feldman, 2011; Swain, 2005; Yang \& Lyster, 2010; Yi \& Sun, 2013). 
Since tasks are seen as tools which have an effect on interaction and the process of negotiation for meaning, it is useful to examine learner interaction when they engage in different communication task types in order to identify how they promote meaningful interaction episodes. However, despite the importance of investigating the potential of communication tasks in promoting meaningful interaction among learners, studies in the Malaysian tertiary context are still scarce. Hence, in order to understand learner interaction processes, there is a need to examine the nature of learner interaction when they engage in different communicative language task types within a local tertiary educational setting. The investigation of this study focused on how the participants interacted during task completion (jigsaw and decision-making) and examined the kind of oral discourse they generated. This study provided an understanding on how different or similar they were in terms of the dynamics of learner interaction and the oral interaction processes involved.

The theoretical perspective of this study on communication tasks and interaction was drawn from the SCT perspective of learning. The SCT framework provides a basis for using tasks that encourage learners to work together and produce language collaboratively. It is believed that communication tasks are effective for language learning because as learners interact, they use language to convey meaning as well as develop meaning (Swain, 2005). When they produce language through collaboration, learners get to do many things all at the same time. They produce output, and while trying to make their meaning precise, they also get help from their peers as well as assist others (Swain, 2005).

\section{METHODOLOGY}

\subsection{Participants}

In Malaysia, despite the recognition given to English as an international language and the government's efforts to ensure that English is taught as a strong second language, the status of English as a second language in Malaysia only means second to Bahasa Malaysia (its national language) in importance. Thus, in Malaysia, English is a foreign language (EFL) which is a term "for the use or study of the English language by non-native speakers in countries where English is generally not a local medium of communication" (http://grammar.about.com/od/e/g/English-As-A-Foreign-Language-Efl.htm).

Following the above, the participants of the study were considered as EFL adult learners. An intact class of 18 EFL participants was chosen, six males and twelve female participants. They were chosen based on several criteria. They were between the ages of 20 and 22 years old and shared the same L1 which was the Malay language. They all studied in religious secondary schools in various states in the country and they formally studied English as a subject for at least 11 years $(6$ years during primary education and 5 years during secondary education). For the study, the learners were placed in groups of three.

\subsection{Tasks}

Two types of communication tasks were used in this study in order to elicit learner interactions from the participants. They were the jigsaw and the decision-making task types. Both task types were meaningoriented tasks. They were chosen due to their different characteristics and capacity to elicit interaction episodes (Pica et al., 1993).

The jigsaw task (J1) used in the present study required the participants to exchange their piece of information with the other members in the team for task completion. The task was a two-way task and believed to provide opportunities for negotiation for meaning among the participants. Thus, the jigsaw task type can be considered "the type of task most likely to generate opportunities for interactants to work toward comprehension, feedback, and interlanguage modification processes related to successful SLA" (Pica et al., 1993, p. 21).

For the decision-making task type, all the participants in the teams possessed similar information. They were required to converge toward a single decision. However, the tasks had more than one outcome option. Moreover, even though the task required a two-way flow of information, interaction among the participants in the team was not really necessary. This was because one participant could actually work independently to make whatever decision required. Hence, it is believed that with such characteristics that the decisionmaking tasks have, "comprehension, feedback, and production opportunities become increasingly reduced" (Pica et al., 1993, p. 22).

\subsection{Procedure}

This study adopted a qualitative approach both in the collection and analysis of the data. Learner interactions were gathered and transcribed verbatim. Transcribed data were examined qualitatively. Qualitative approach 
in the context of this study was deemed suitable as the aim of this study was to examine interaction among EFL learners through the use of different communication task types. The approach emphasizes the process rather than the outcomes (Bogdan \& Biklen, 2007; Merriam, 2001). According to Bogdan and Biklen (2007), "qualitative researchers are concerned with process rather than simply outcomes or products" (p. 6) and the qualitative emphasis on process has been particularly beneficial in educational research. Hence, by using the qualitative approach in data collection and analysis, the researchers involved in this study were able to gain in-depth understanding on how the participants interacted when they engaged in the two task types and the kind of oral discourse they generated.

\subsection{Data analysis}

In order to examine how the participants interacted as they engaged in task completion and the kind of oral discourse they generated, attention needed to be paid to moment-by-moment nature of interaction. To do this, Kumpulainen and Wray's (2002) three-level parallel analysis was chosen and adapted with modifications. This analysis framework, which has the sociocultural and socio-cognitive perspectives to interaction and learning as its theoretical grounding, allows the dynamics of learner interactions to be approached from three analysis dimensions.

The three-level parallel analysis consists of three dimensions; the functional analysis, the cognitive processing and the social processing. The first dimension is analysis of discourse functions (functional analysis). This analysis focuses on the functions of learners' verbal communication. It aims at investigating the purposes for which language is used in a given context (Halliday \& Hasan, 1989). The second dimension is the analysis of cognitive processing. It examines the ways in which learners approach and process learning tasks in their social interaction. This dimension looks at learners' working strategies and situated positions toward learning, knowledge and problem-solving. Cognitive processes are seen as dynamic and contextual in nature. They are socially constructed in learners' growing interactions. The final dimension is the analysis of social processing. When analyzing learners' social processing in learner interactions, the emphasis is on the nature of learners' collaboration - how they collaborate or their mode of collaborative work. Generally, the different modes are "collaborative, tutoring, argumentative, individualistic, dominative, conflict and confusion modes" (Kumpulainen \& Wray, 2002, p. 38)

For the present study, the analysis conducted focused on the social processing aspect. When analyzing learners' social processing in learner interaction, the emphasis was on the nature of learners' collaboration. The social processing provided an understanding on how the participants interacted as they engaged in task completion which included whether there was evidence of collaboration in their learner interaction and the kind of oral discourse they generated.

\section{RESULTS}

The study reported in this paper was part of a wider study. However, for this paper, the investigation focused on the social processing aspect which was how the participants interacted as they engaged in task completion and the kinds of oral discourse they generated. It aimed to answer the following research question;

How do EFL learners interact using different communication task types and what kind of oral discourse is generated?

\subsection{Social Processing}

When analyzing learners' social processing in learner interaction during task completion, it was observed that during their discussion, the participants engaged in collaborative interactions. Episodes of collaborative interactions were evident as the participants jointly made meaning in order to understand the information and negotiated ideas. However, the kind of collaborative interactions generated differed between one task type and the other i.e. jigsaw and decision-making tasks. The learner interactions generated during jigsaw task completion exhibited close collaboration with some negotiation as the participants tried to make meaning together. As seen in Excerpt 1, Mohd provided an explanation to Jani about the position of the lake, island and hill in the picture. Jani repeatedly asked questions to ensure correct understanding. Both Mohd and Jani jointly investigated the information they had and made meaning together. This is an episode of joint investigation and joint meaning-making to achieve mutual understanding of the materials, an evidence of collaboration.

\section{Excerpt 1 Jigsaw (Joint Meaning-making)}

Mohd: $\quad$ On the middle and around the hill. 
Jani: $\quad$ Around the island has hill so there is a hill around the island?

Mohd: $\quad$ Yes.

Jani: $\quad$ Around the island ke around the lake?

Mohd: $\quad$ Around the lake.

Jani: $\quad$ Seluruh tasik?

Mohd: $\quad$ Lake like this, lake hill island on the middle.

Jani: Nilake.

Mohd: $\quad$ Like this.

Jani: $\quad$ Ok, ni lake.

Mohd: $\quad$ Middle.

Jani: $\quad$ Where is the hill? (giggle) Ni hill.

Mohd: $\quad$ Oh no lake, I think, er, ok, there is an island sana island like this.

Jani: $\quad$ Ok, island.

Mohd: $\quad$ Ok, this is island. Ok, the middle of lake.

Jani: Nilake?

Mohd: Ha, lake.

Hartini: Then the hill.

Mohd: $\quad \mathrm{Ha}$, the hill a big tree.

Hartini: $\quad$ Tasik yang besar.

Mohd: $\quad$ Sini tasik sini lake.

(J2/Brown/68-88)

A different kind of collaborative interaction could be observed when the participants engaged in the decisionmaking task completion. When the participants jointly made meaning, their learner interactions were exploratory and highly collaborative with evidence of intensive negotiation. They negotiated ideas and provided extended explanation in order to achieve mutual understanding. When compared to the jigsaw learner interactions, despite being collaborative when engaged in jigsaw task completion, their interactions were quite straight forward with some evidence of negotiation. Excerpt 2 illustrates the collaborative interaction generated by the participants when they completed the decision-making task. They negotiated their ideas and together they tried to make meaning. Hartini pointed out the picture which she thought showed air pollution. The rest of the participants in the team agreed after a short discussion. Then Mohd shared his opinion regarding the picture that showed water pollution. However, Hartini expressed disagreement and provided her explanation. Jani and Mohd shared similar understanding and tried to convince Hartini by explaining to her. However, Hartini was adamant about what she thought and tried to convince the others in her team. Eventually, they all agreed to have two types of pollution, water and sea pollution, as suggested by Mohd (lines 49-50). Evidence of raising questions and investigation of the materials can be seen in their learner interactions as they explored them together. Their learner interactions were highly collaborative with episodes of intensive negotiation.

\section{Excerpt 2 Decision-making (Joint Meaning-making)}

Hartini: $\quad$ The air pollution.

Mohd: $\quad$ Air pollution?

Hartini: $\quad$ Air pollution.

Jani: Where?

Hartini: This picture.

Jani: Ha! 


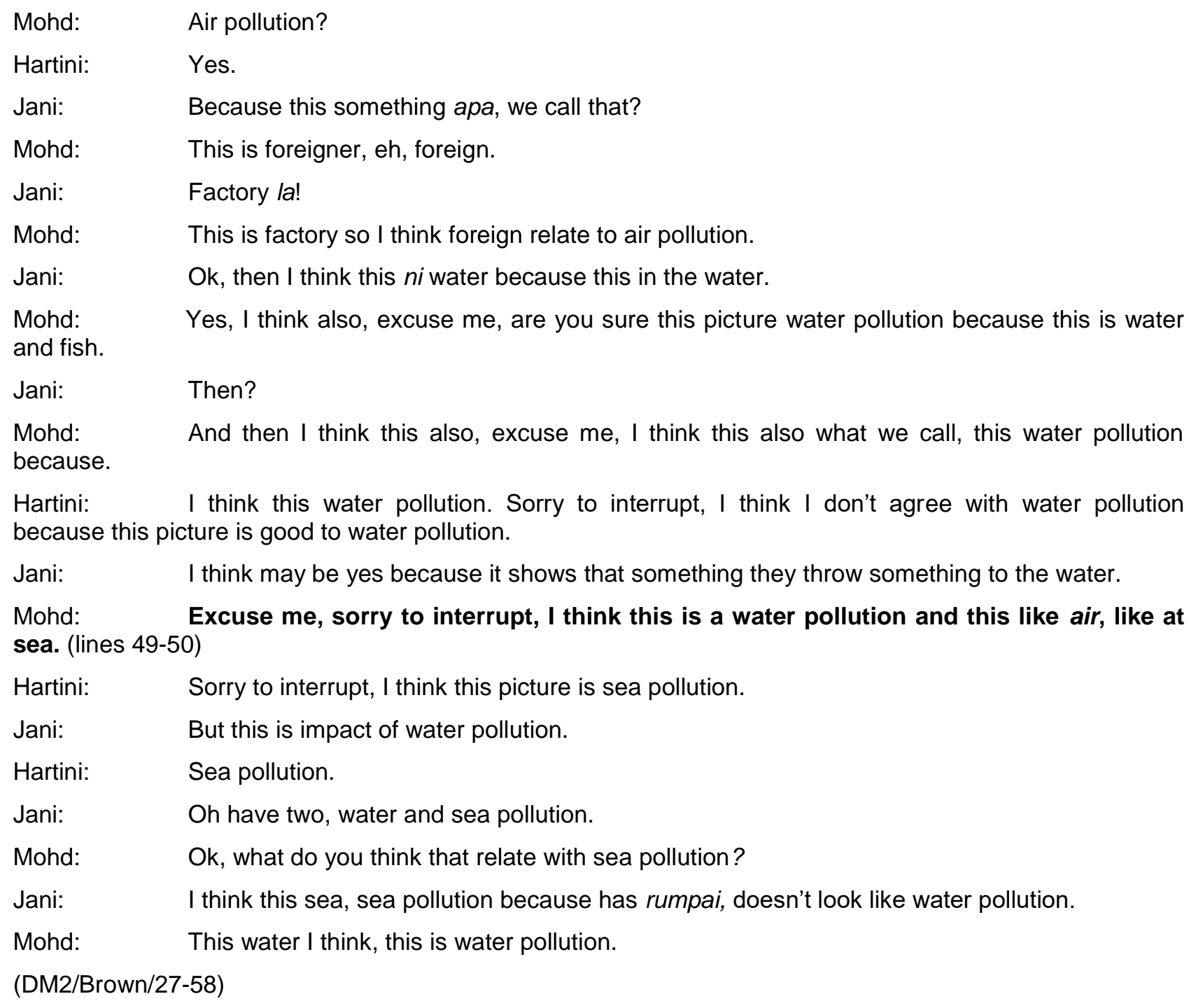

\subsection{Argumentative Episodes}

This section reports on the kinds of oral discourse the participants generated when engaged in task completion. Apart from being characterized by joint investigation and joint meaning-making, the collaborative interaction was also characterized by argumentative episodes. Argumentative mode did not imply that the participants argued with one another during their discussion. Instead, they negotiated their differences and resolved conflicts by arguing their points in a rationale way. They provided reasons and justifications in order to achieve a shared understanding of the situation. Judgments and justifications normally led to a shared understanding of the situation. The argumentative episodes were found in the participants' learner interactions when they engaged in both task types.

When engaged in the jigsaw task completion, the argumentative episodes identified were short and straight forward with some explanations given. This was because what the participants wanted to achieve was to understand the input to ensure accurate completion of the tasks. As seen in Excerpt 3, Hartini tried to explain to her team what an anemone was. She tried to explain the meaning of the word to both Mohd and Jani but they could not understand. Mohd argued with her insisting that an anemone was not an animal as claimed by Hartini. She explained further (lines 109, 111, 113, 115 \& 117) and finally Mohd understood and accepted her explanation (line 119).

\section{Excerpt $3 \quad$ Jigsaw (Argumentative)}

Hartini: $\quad$ Then the tide pool also has a sea anemone like look, like flower but they are animals that catch and eat other animals with their flower like part.

Mohd: $\quad$ You mean the animal like flower? 
Hartini: $\quad$ No, in tide pool also have a sea anemone that like flower. (line 109)

Mohd: $\quad$ Oh, like rumpai.

Hartini: $\quad$ But they are animal. (line 111)

Mohd: $\quad$ This still rumpai, but not animal.

Hartini: $\quad$ No, like flower. (line 113)

Jani: $\quad$ Animal like flower.

Hartini: $\quad$ No, rumpai laut. (line 115)

Jani: [giggle]

Hartini: $\quad$ Sejenis bunga. (line 117)

Jani: $\quad$ Tapi sejenis binatang.

Mohd: $\quad$ Ok, I know. (line 119)

(J1/Brown/106-119)

A different kind of learner interaction consisting of argumentative episodes was observed when the participants engaged in the decision-making task completion which could be observed in Excerpt 4 . In this excerpt, intensive negotiation and argumentative instances could be observed as the participants worked on the materials they had. They discussed the best possible way to present their ideas in writing. Faizal shared his idea on what to write first. However, Wan did not appear to agree, he had different views and challenged Faizal's idea. They argued and negotiated intensively before reaching an agreement (e.g. lines 211, 212$213,214-215,216,218 \& 219)$. In this episode, instances of ideas or opinions being challenged with intensive negotiation could be observed. Arguments and disagreements led to ideas being challenged and explanations being sought by the participants.

\section{Excerpt $4 \quad$ Decision-making (Argumentative)}

Aina: $\quad$ Logging are divide. Logging....are divide....into...two.

Faizal: I think we should not mention two. We just logging are divide into legal and illegal activity.

Aina: $\quad$ Legal and illegal activity?

Wan: Effect the logging.

Faizal: $\quad$ Nowadays in Malaysia has many... (line 211)

Wan: Nowadays? Why should we do the first paragraph is effect, second paragraph is suggestion...to....rmmm (lines 212-213)

Faizal:

(lines 214-215)

Wan: I think nowadays is not suitable. (line 216)

Faizal: Ok.

Wan: $\quad$ Nowadays? (line 218)

Faizal: $\quad$ So what is your suggestion? (line 219)

Wan: No, no, not nowadays. What, what your sentence?

Faizal: $\quad$ Nowadays so many illegal logging activity at Malaysia.

Wan: $\quad$ At or in?

Faizal: $\quad$ At. This activity gives many effect.

Aina: $\quad$ Ok, ok. We use this. Nowadays? What?

Faizal: $\quad$ Nowadays, so many...illegal.

Aina: [Activity]

Wan: So many illegal. 
Faizal: I think before illegal activity is illegal logging activity.

Wan: Logging activities.

Faizal: In or at?

Aina: In.

Faizal: $\quad$ In Malaysia.

(DM2/Red/206-232)

\section{DISCUSSION}

In this study, the link between different communication task types and learners' oral discourse could be understood in the light of the SCT perspective. It places emphasis on the importance of interaction and output in L2 learning and support the use of task-based activities in a language classroom. By analyzing data from learner interactions elicited during task completion of peers within the SCT framework, the researchers could understand how "learners in a guided pair work interactive context move forward in their acquisition of the L2, sharing their strengths through the process of collaborative learning" (Ohta, 1995, p. 117).

The research question concerned how EFL learners interacted using different communication task types and the kind of oral discourse they generated. When engaged in task completion for both task types, it was observed that close collaboration was evident throughout the learner interactions. The collaborative interaction was highlighted by episodes of joint meaning-making and was characterized mainly by episodes of asking for clarification and asking for more explanation. These episodes gave evidence of joint meaningmaking among them in trying to build and achieve inter-subjectivity (Wells, 1986). The element of intersubjectivity is very much related to collaboration and occurs through constant negotiation. However, when observed closely, during the decision-making task completion the participants' learner interactions were highly collaborative with evidence of intensive negotiation compared to when engaged in the jigsaw task completion. The participants intensively negotiated ideas and provided extended explanation in order to achieve mutual understanding. They generated complex patterns of interaction when they negotiated ideas. Their interaction episodes were not straight forward as they took time to explain as seen in Excerpt 2. Findings showed that the decision-making task type was the type that encouraged the production of complex patterns of interactions and the generation of more complex ideas.

Another significant finding was the existence of argumentative interaction episodes. Instances of disagreement were observed. These episodes were observed to occur when the participants tried to jointly make meaning especially while writing together. They argued on contents, sentence structures and word choices. They also revised what they had composed by either changing or modifying it. The collaborative writing encouraged them to engage in interactional modifications and produced modified output during their learner interactions. This can be observed in both Excerpts 3 and 4 . It is believed that when the participants engaged in argumentative mode and produced modified output during their learner interactions, not only did they push themselves, the whole process may assist them to "control and internalize linguistic knowledge" (Swain, 1995, p. 126). This is very much in line with Vygotsky's SCT argument that knowledge is created and internalized through interaction.

However, when closely observed, it was during the decision-making task completion that the participants engaged more extensively in argumentative episodes with evidence of intensive negotiation than in the jigsaw task completion. The participants presented their arguments explicitly and provided support to maintain their opinions. Strategies and solutions were also jointly created and tested. The participants' collaborative interactions, characterized by intensive negotiation and argumentative episodes reflected intensive task engagement where a lot of effort was put in to explore and communicate ideas, as well as to provide suggestions and explanations. During interaction, when there was a difference of opinion among the participants, episodes of questioning, asking for clarification and reasoning emerged as they need to solve the difference of opinion. It is argued that clarification requests found in argumentative episodes are related to critical thinking and problem solving (Chin \& Osborne, 2010; Rogoff, 1990). Further, argumentation which includes episodes of questioning and reasoning is an important feature of effective interaction (Cohen, 1994). In this study, it was the decision-making tasks that encouraged the production of interactional and linguistics modifications coupled with interaction episodes which were argumentative in nature with rigorous negotiations.

Understanding the dynamics of learner interactions during different task completion has crucial pedagogical implication. This knowledge can be used as a basis for informed pedagogical practice in the L2 classroom particularly in an EFL context. Findings revealed that when they interacted, they did not just produce 
language and make modifications. They engaged in collaborative interactions and explored ideas through dialogue. They produced complex patterns of interactions and generated more complex ideas. Their collaborative interaction was also characterized by argumentative episodes. These collaborative interactions characterized by argumentative episodes generated more complex ideas to emerge and to be negotiated in interaction. Basturkmen (2002) argues that complex patterns of interactions are "important in enabling students to develop their own ideas in discussion" (p. 233). When engaged in these complex patterns of interactions, learners are able to articulate thoughts and clarify thinking more clearly. It is these kinds of interactions that are important particularly for learners at the tertiary level. Based on the results of the present study, it was observed that the decision-making task type was the type that encouraged the production of complex patterns of interactions and the generation of more complex ideas as found in their interaction episodes. The participants were able to generate the kind of interaction episodes believed to be facilitative of their language learning. Depending on the objectives of language lessons, this knowledge can guide language practitioners when deciding to include communication tasks in their language classrooms.

Findings also expand the understanding of the characteristics of communication language tasks. While requests for clarification can be encouraged using communication language tasks, findings from this study revealed that the tasks can also be used and manipulated to encourage and develop argumentative skills particularly the decision-making tasks. Engaging in the argumentative use of language encourages learners to think critically and evaluate their understanding as well as justify their opinions. These are highly valued in education and are particularly important for learners at the tertiary level to develop (Cohen, 1994; Mercer, Phillips \& Somekh, 1991). Hence, pedagogically, the use of decision-making tasks should be encouraged more as they provide learners with opportunities to develop their language abilities to reason and argue.

\section{CONCLUSIONS}

Results from this study illustrate how the different communication tasks affect the dynamics of learner interaction and shape the kind of oral discourse they generate which in turn promote language development and learning in general. The findings confirm the positive relationships that exist between communication tasks and interaction. They further illustrate the task type that encouraged the production of complex patterns of interactions and the generation of complex ideas is believed to be important particularly for learners at the tertiary level. While the findings from this study have its contribution, future research is recommended. Firstly, even though the study is relevant to an EFL tertiary level context in general, the findings are specific to a given classroom context where the data were obtained. This is because the participants in this study shared several unique features/characteristics. All the participants were from the same ethnic group (i.e. Malay), shared the same L1 (i.e. Malay language) and were all Malaysians. Furthermore, they also shared similar secondary school background, which was the Islamic religious secondary school background. Thus, given these unique characteristics, the results of this study cannot be taken to be representative of learners in other institutions of higher learning in Malaysia or other EFL contexts. The results cannot be generalized to other L2 teaching and learning contexts either. However, although generalizability of the study may be limited due to the unique composition of the participants, there are elements of the results which may be transferable to other research contexts. The result of this study can still be of benefit to other researchers. As highlighted by Guba and Lincoln (1989), the issue in qualitativeinterpretive research is transferability rather than generalizability. One type of transferability is known as naturalistic generalizability (Stake, 1995). Naturalistic generalization is when the "individual reader determines whether the research findings are transferable" and "the degree of transferability can vary depending on the experience, awareness, and knowledge of the reader" (Bailey, 2007, p. 183). Thus, for this study, instead of making generalization, other researchers or readers may themselves determine the extent to which findings can be applied or transferred to their EFL situations.

\section{ACKNOWLEDGEMENTS}

This research was financially supported by the Ministry of Education, Malaysia.

\section{REFERENCE LIST}

Bailey, C. A. (2007). A guide to qualitative field research (2nd ed.). Thousand Oaks, CA: Pine Forge Press.

Basturkmen, H. (2002). Negotiating meaning in seminar-type discussion and EAP. English for Specific Purposes, 21(3), 233-242.

Bogdan, R. C., \& Biklen, S. K. (2007). Qualitative research for Education: An introduction to theories and methods (5th ed.). Boston, MA: Pearson. 
Brooks, F., Donato, R., \& Mcglone, V. (1997). When are they going to say 'it' right? Understanding learner talk during pair-work activity. Foreign Language Annals, 30(4), 524-541.

Bygate, M., Skehan, P., \& Swain, M. K. (Eds.). (2001). Researching pedagogic tasks: Second language learning, teaching and testing. New York, NY: Longman.

Cohen, E. (1994). Restructuring the classroom: Conditions for productive small groups. Review of Educational Research, 64(1), 1-35.

Donato, R. (1994). Collective scaffolding in second language learning. In J. P. Lantolf \& G. Appel (Eds.), Vygotskian approaches to second language research (pp. 33-56). Norwood, NJ: Ablex.

Ellis, R. (1999). Learning a Second Language through Interaction. Philadelphia PA: John Benjamins Publishing Company.

Ellis, R. (2004). Task-based language learning. Oxford, UK: Oxford University Press.

Franco, M. E. P. (1996). Designing a writing component for teen courses at a Brazilian language institute. In Kathleen G. (Ed.), Teachers as course developers (119-150). Cambridge, UK: Cambridge University Press.

Gerlach, J. M. (1994). Is this collaboration? New Directions in Teaching and Learning, 59, 5-14.

Guba, E., \& Lincoln, Y. (1989). Fourth generation evaluation. Newbury Pak, CA: Sage.

Halliday, M. A. K., \& Hasan, R. (1989). Language, context, and text. London, UK: Oxford University Press.

http://grammar.about.com/od/e/g/English-As-A-Foreign-Language-Efl.htm

Kumpulainen, K., \& Wray, D. (Eds). (2002). Classroom interaction and social learning: From theory to practice. New York, NY: Routledge Falmer.

Lantolf, J. P. (2000). Second language learning as a mediated process. Language Teaching, 33(2), 79-96.

Lee, J. F. (2000). Tasks and communicating in language classrooms. Boston, MA: McGraw-Hill.

Mackey, A. (2007). Introduction: the role of conversational interaction in second language acquisition. In A. Mackey (Ed.), Conversational interaction in second language acquisition: A collection of empirical studies (pp. 1-25). Oxford, UK: Oxford University Press.

Mercer, N., Phillips, T. \& Somekh, B. (1991). Research notes, spoken language and new technology (SLANT). Journal of Computer Assisted Learning, 7, 195-202.

Merriam, S. B. (2001). Qualitative research and case study applications in Education. San Francisco, CA: Jossey-Bass.

Nassaji, H., \& Tian, J. (2010). Collaboative and individual output tasks and their effects on learning English phrasal verbs. Language Teaching Research, 14(4), 397-419.

Nuevo, A. M., Adams, R., \& Ross-Feldman, L. (2011). Task complexity, modified output, and L2 development. In P. Robinson (Ed.), Second language task complexity: Researching the cognition hypothesis of language learning and performance (pp. 175-204). Philadelphia, PA: John Benjamins.

Ohta, A. S. (1995). Applying sociocultural theory to an analysis of learner discourse: Learner-learner collaborative interaction in the Zone of Proximal Development. Issues in Applied Linguistics, 6(2), 93121.

Olsen, J. W.-B., \& Kagan, S. (1992). About cooperative learning. In C. Kessler (Ed.), Cooperative language learning (pp. 1-30). Englewood Cliffs, NJ: Prentice Hall.

Pica, T., Kanagy, R., \& Falodun, J. (1993). Choosing and using communicative tasks for second language instruction. In Crookes, G. \& Gass, S. (Eds.), Tasks and language learning: Integrating theory and practice (pp. 9-34). Clevedon, UK: Multilingual Matters.

Rogoff, B. (1990). Apprenticeship in Thinking: Cognitive Development in Social Context. New York: Oxford University Press.

Stake, R. (1995). The art of case study research. Thousand Oaks, CA: Sage.

Swain, M. (2000). The output hypothesis and beyond: Mediating acquisition through collaborative dialogue. In P. Lantolf (Ed.), Sociocultural theory and second language learning (pp. 97-114). Oxford: Oxford 
University Press.

Swain, M. (2005). The output hypothesis: Theory and research. In E. Hinkel (Ed.), The handbook of research in second language teaching and learning (pp. 471-483). Mahwah, NJ: Erlbaum.

Swain, M., \& Lapkin, S. (2000). Task-based second language learning: The uses of the first language. Language Teaching Research, 4(3), 251-274.

Swain, M., \& Lapkin, S. (2001). Focus on form through collaborative dialogue: Exploring task effects. In Bygate, M., Skehan, P. \& Swain, M. (Eds.), Researching pedagogic tasks: Second language learning, teaching and testing (pp. 99-118). Essex, UK: Pearson Education.

Swain, M., \& Lapkin, S. (2002). Talking it through: Two French immersion learners' response to reformulation. International Journal of Educational Research, 37(3), 285-304.

Vygotsky, L. S. (1978). Mind in society: The development of higher psychological processes. Cambridge, MA: Harvard University Press.

Wells, G. (1986). The meaning makers: Children learning language and using language to learn. Portsmouth, NH: Heinemann Educational Books.

Yang, Y., \& Lyster, R. (2010). Effects of form-focused practice and feedback on Chinese EFL learners' acquisition of regular and irregular past tense form. Studies in Second Language Acquisition, 32(2), 235-263.

Yi, B., \& Sun, Z. (2013). An empirical study of the effectiveness of negotiation of meaning in L2 vocabulary acquisition of Chinese learners of English. English Language Teaching, 6(10), 120-131. 